26. Fan, B. et al., Genetic variation analysis within and among Chinese indigenous swine populations using microsatellite markers. Anim. Genet., 2002, 33, 422-427.

27. Kijas, J. M. and Andersson, L., A phylogenetic study of the origin of the domestic pig estimated from the near-complete mtDNA genome. J. Mol. Evol., 2001, 52, 302-308.

28. Yu, G., Xiang, H., Wang, J. and Zhao, X., The phylogenetic status of typical Chinese native pigs: analyzed by Asian and European pig mitochondrial genome sequences. J. Anim. Sci. Biotechnol., 2013, 4, 9.

29. Li, K. Y., Li, K. T., Cheng, C. C., Chen, C. H., Hung, C. Y. and Ju, Y. T., A genetic analysis of taoyuan pig and its phylogenetic relationship to eurasian pig breeds. Asian-Australas. J. Anim. Sci., 2015, 28, 457-466.

30. Rothschild, M. F. and Ruvinsky, A., The Genetics of the Pig, CPI Antony Rowe, Chippenham, London, UK, 2011, 2nd edn.

31. Tran, V. P., Husbandry Techniques of the Breeding Snows, Labour Publishing House, Hanoi, Vietnam (in Vietnamese), 2005.

32. Luetkemeier, E. S., Sodhi, M., Schook, L. B. and Malhi, R. S., Multiple Asian pig origins revealed through genomic analyses. Mol. Phylogenet. Evol., 2010, 54, 680-686.

33. Megens, H. J., Crooijmans, R. P., San Cristobal, M., Hui, X., Li, N. and Groenen, M. A., Biodiversity of pig breeds from China and Europe estimated from pooled DNA samples: differences in microsatellite variation between two areas of domestication. Genet. Sel. Evol., 2008, 40, 103-128.

ACKNOWLEDGEMENT. This research was funded by the Vietnam National Foundation for Science and Technology Development (NAFOSTED) under grant number: 106-NN.05-2014.66.

\section{Early Oligocene (Rupelian) dinoflagellate cysts and calcareous nannofossils from Lumpy Clay Member of Maniyara Fort Formation, Kutch, Gujarat, India}

\author{
Poonam Verma* and Abha Singh \\ Birbal Sahni Institute of Palaeosciences, 53-University Road, \\ Lucknow 226 007, India
}

The Palaeogene succession of Kutch, Gujarat exhibits huge shallow marine carbonate deposits of Middle Eocene and Oligocene ages. These deposits were mainly dated on the basis of larger benthic foraminifers. The paucity of foraminifers in the intermittent units of the succession resulted in discrepancy in

*For correspondence. (e-mail: verma.poonam07@gmail.com) precise dating of these strata. Lumpy Clay Member of Maniyara Fort Formation is one such example. This is considered as unfossiliferous in terms of foraminifers and was dated on the basis of foraminiferal assemblages of underlying Basal and overlying Coral Limestone members. In the present study, palynological biostratigraphy is proposed for the Lumpy Clay Member exposed at Bermoti Village, in Kutch. On the basis of age-diagnostic calcareous nannofossil and dinoflagellate cyst assemblages, the studied succession has been dated as Middle Rupelian ( $31 \mathrm{Ma})$. The palynological data suggests a shallow marine neritic depositional setting, occasionally swept by open oceanic water.

Keywords: Calcareous nannofossils, dinoflagellate cysts, Kutch, Lumpy Clay Member, Maniyara Forth Formation, Rupelian.

DURING the Eocene-Oligocene transition, intense climatic and oceanographic changes occurred coupled with the first major continental-scale glaciation of Antarctica ${ }^{1,2}$. These complex series of events occurred over an extended period between $\sim 33.5$ and $34.0 \mathrm{Ma}$, causing environmental disturbances that led to a global biotic turnover seen in both terrestrial and marine records of shallow-water and deep-sea environments. Spanning this transition interval, many thick Cenozoic limestone deposits containing larger benthic foraminifers are common within the Indo-Pacific region ${ }^{3-6}$. However, due to lowered global sea level during the Eocene-Oligocene transition, many stratigraphic sections are incomplete, with hiatuses or unconformities. In India, the Amravati Formation of Cambay Basin ${ }^{7}$ and Fulra and Maniyara Fort formations of Kutch $\operatorname{Basin}^{8-10}$ are considered to be among the most complete sections with some hiatuses.

The Kutch sedimentary basin in the western continental margin of India is a peri-cratonic rift basin which archives almost complete sedimentary records from Middle Jurassic to the present, interrupted by several episodes of non-deposition. The nearly complete, richly fossiliferous and easily accessible outcrops of Cenozoic sediments exposed in the western part of the Kutch mainland extend offshore into the present-day continental shelf.

Particularly, the marine Oligocene outcrops in the western part of Kutch have been initially recognized under the Nari Series of Pakistan ${ }^{11,12}$. Later, Biswas and Raju $^{13}$, and Biswas ${ }^{14}$ designated the Oligocene strata of Kutch as the Maniyara Fort Formation (Table 1), exposed in a type section near Bermoti Village along the Bermoti River. The Maniyara Fort Formation consists of a succession of bedded, yellow to ochre-coloured foraminiferal limestone with a basal greyish-green glauconitic siltstone overlying the Middle Eocene Fulra Limestone. The formation is richly fossiliferous with a variety of echinoids, pelecypods, gastropods, corals, foraminifers and crabs. Nummulites fichteli and Miogypsinoides are the 
Table 1. Lithostratigraphic classification and regional chronostratigraphic units of late Palaeogene-Neogene successions in Kutch, Gujarat (after Biswas) ${ }^{14}$

\begin{tabular}{|c|c|c|c|c|c|c|}
\hline$\underset{\Xi}{\sum_{\Xi}^{\Xi}}$ & \multicolumn{2}{|c|}{$\underset{n}{\infty}$} & STAGES & $\begin{array}{l}\text { LITHOSTRATIGRAPHY } \\
\text { FORMATIONS }\end{array}$ & MEMBERS & $\begin{array}{l}\text { W. COAST/ } \\
\text { KUTCH STAGES }\end{array}$ \\
\hline \multirow{2}{*}{$10-$} & \multirow[b]{2}{*}{$\sum_{0}^{-1}$} & ؛ัँ & $\begin{array}{l}\text { Messinian } \\
\text { Tortonian }\end{array}$ & \multirow{2}{*}{ SANDHAN } & & \multirow{2}{*}{$\begin{array}{l}\text { KANKAWATIAN } \\
\text { SUPER STAGE }\end{array}$} \\
\hline & & $\stackrel{\stackrel{0}{g}}{\stackrel{0}{g}}$ & Langhian & & & \\
\hline \multirow{3}{*}{ 20- } & \multirow{3}{*}{$\underline{z}$} & \multirow{3}{*}{ ؛ัँ } & \multirow{2}{*}{ Burdigalian } & \multirow{2}{*}{ CHHASRA } & Siltstone & \multirow{2}{*}{ VINJHANIAN } \\
\hline & & & & & Claystone & \\
\hline & & & Aquitanian & KHARI NADI & & AIDAIAN \\
\hline \multirow{2}{*}{$30-$} & \multirow{2}{*}{$\begin{array}{l}Z \\
Z \\
0 \\
0 \\
0 \\
0 \\
0 \\
0 \\
0\end{array}$} & $\frac{\grave{\Xi}}{2}$ & Chattian & \multirow{2}{*}{ MANIYARA FORT } & Bermoti & WAIORIAN \\
\hline & & 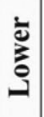 & Rupelian & & $\begin{array}{l}\text { Coral Limestone } \\
\text { Lumpy Clay } \pitchfork \\
\text { Basal Member }\end{array}$ & RAMANIAN \\
\hline \multirow{3}{*}{$40-$} & \multirow{3}{*}{ 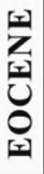 } & $\frac{\grave{\Xi}}{\frac{2}{2}}$ & Priabonian & \multirow{3}{*}{ FULRA LIMESTONE } & & \\
\hline & & 르 & Bartonian & & & \multirow[b]{2}{*}{ BABIAN } \\
\hline & & $\dot{z}$ & Lutetian & & & \\
\hline
\end{tabular}

characteristic foraminifers present. This formation is divided into four members: (1) the Basal Member consisting of alternating beds of foraminiferal, glauconitic, brownish to yellowish siltstone and calcareous, gypseous claystone; (2) the Lumpy Clay Member consisting of cement-coloured to brownish calcareous, lumpy claystone, occasionally containing thin limestone and marlite beds; (3) the Coral Limestone Member consisting of dirty white-coloured nodular limestone alternating with calcareous claystone in the lower part, and grey to dirty white-coloured massive limestone with abundant corals bioherms in the upper part; (4) the upper Bermoti Member consisting of rusty brown, friable glauconitic argillaceous sandstone. The upper part of this member is composed of thinly bedded, very hard, grey to yellowish foraminiferal limestone with interbeds of silty marlite full of Spiroclypeus.

The lower three members - Basal, Lumpy Clay and Coral Limestone-correspond to the Lower Oligocene Ramanian Stage (Rupelian) ${ }^{15,16}$, while the uppermost Bermoti Member corresponds to the Upper Oligocene Waiorian Stage (Chattian) ${ }^{15,17}$. Interestingly, the Ramanian Stage is characterized by larger foraminifera Eulepidina dilatata and Nummulites fichteli recovered from the Basal and Coral Limestone members, whereas interbed- ded Lumpy Clay Member is reportedly unfossiliferous ${ }^{18}$. The present study provides an integrated palynological biostratigraphy of calcareous nannofossils, dinoflagellate cysts and sporomorphs from the sediment samples of Lumpy Clay Member of Maniyara Fort Formation, to precisely date and reconstruct the depositional environment based on new fossil data.

In this study recovery of dinoflagellate cysts has been recorded from four samples of Lumpy Clay Member of Maniyara Fort Formation exposed at Bermoti River section (Figure 1) $\left(23^{\circ} 27^{\prime} 44.3^{\prime \prime} \mathrm{N}\right.$ : $\left.68^{\circ} 36^{\prime} 8.8^{\prime \prime} \mathrm{E}\right)$ following standard preparation techniques. Initially, crushed samples were treated with $10 \% \mathrm{HCl}$ and $40 \% \mathrm{HF}$ to remove carbonates and silicates respectively. Then the residue was treated with dilute $\mathrm{HNO}_{3}$ and washed repeatedly at every step. The residue was sieved using a $15 \mu \mathrm{m}$ sieve. After staining the macerate with safranin, permanent slides were prepared using polyvinyl and Canada balsam. The palynomorphs were photographed using a microscope (Nikon Eclipse i90) attached with a digital camera (Cannon). Figures 2 and 3 show the important specimens. All the photomicrographs are provided with the England Finder position on their respective slides in the figure legends. The slides have been deposited in the museum of the Birbal Sahni Institute of Palaeosciences 

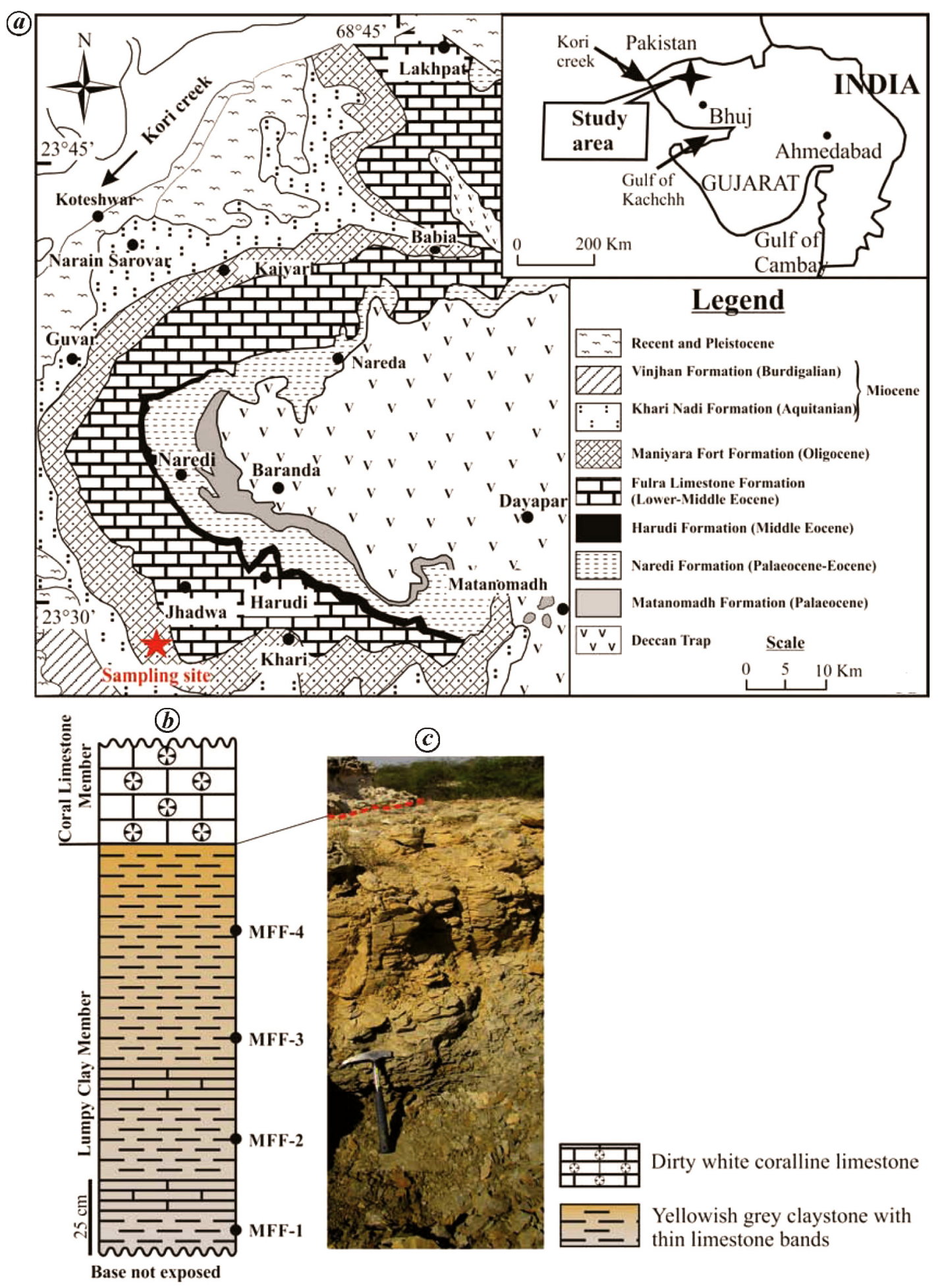

Figure 1. $\boldsymbol{a}$, Geological map of the Kutch region, Gujarat, western India with location of the study area marked by a star (after Biswas) $^{14}$. b, A general litholog. $\boldsymbol{c}$, A field photograph of the studied succession of Lumpy Clay Member of Maniyara Fort Formation exposed along Bermoti River section in Kutch.

(BSIP), Lucknow with repository numbers 1627516282.

For the study of nannofossils, smear slides of all four samples were prepared following standard method ${ }^{19}$.
About $2 \mathrm{~g}$ of sample was used for slide preparation and the slides were scanned under a polarized microscope (Leica DM2500 P). Photomicrographs were taken under $100 \times$ objective with immersion oil (Figure 4) and the 


\section{RESEARCH COMMUNICATIONS}
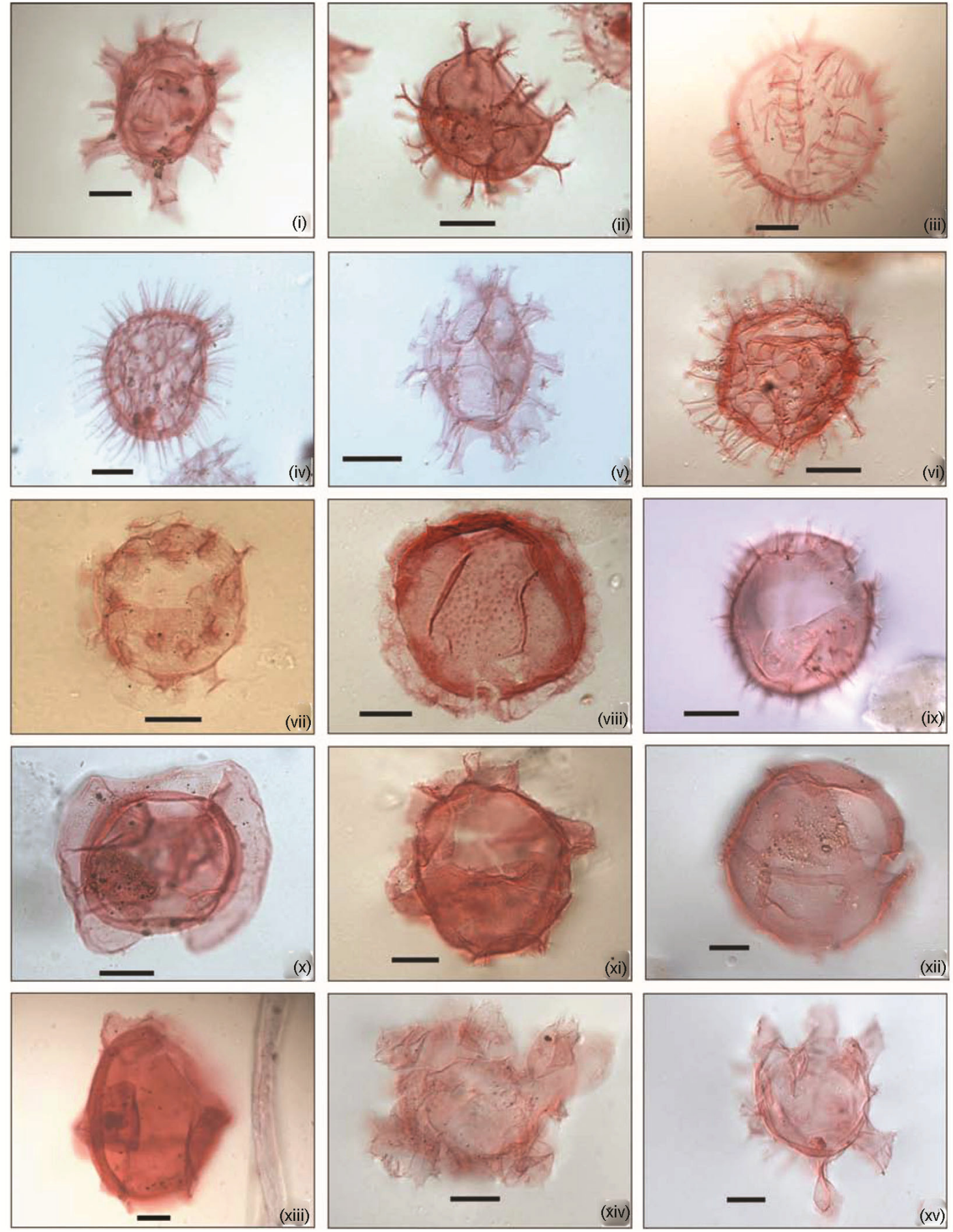

Figure 2. (i) Achilleodinium biformoides (Eisenack, 1954) Eaton, 1976, BSIP slide no. 16275, F52. (ii) Achomosphaera alcicornu (Eisenack, 1954) Davey and Williams, 1966, BSIP slide no. 16276, M39. (iii) Polysphaeridium congregatum (Stover, 1977) Bujak et al., 1980, BSIP slide no. 16277, J53/2. (iv) Impletosphaeridium machaeroides Stover and Hardenbol, 1994, BSIP slide no. 16275, V39/1. (v) Spiniferites pseudofurcatus (Klumpp, 1953) Sarjeant, 1970, BSIP slide no. 16278, T42. (vi) Cleistosphaeridium diversispinosum (Davey et al., 1966) Eaton et al., 2001, BSIP slide no. 16279, O32. (vii) Tuberculodinium vancampoae (Rossignol, 1962) Wall, 1967, BSIP slide no. 16279, V52. (viii) Cyclopsiella granosa (Matsuoka, 1983) Head et al., 1992, BSIP slide no. 16279, F61/3. (ix) Lingulodinium machaerophorum (Deflandre and Cookson, 1955) Wall, 1967, BSIP slide no. 16280, E49. (x) Pentadinium laticinctum Gerlach, 1961, BSIP slide no. 16281, E51/4. (xi) Pentadinium sp., BSIP slide no. 16279, W39/2. (xii) Impagidinium elegans (Cookson and Eisenack, 1965) Stover and Evitt, 1978, BSIP slide no. 16280, M40. (xiii) Impagidinium sp., BSIP slide no. 16277, M53/2. (xiv) Hystrichokolpoma globulus Michoux, 1985, BSIP slide no. 16282, V36/4. (v) Hystrichokolpoma rigaudiae Deflandre and Cookson, 1955, BSIP slide no. 16282, M39/4. Scale bar $=10 \mu \mathrm{m}$ for each photomicrograph. 


\section{RESEARCH COMMUNICATIONS}
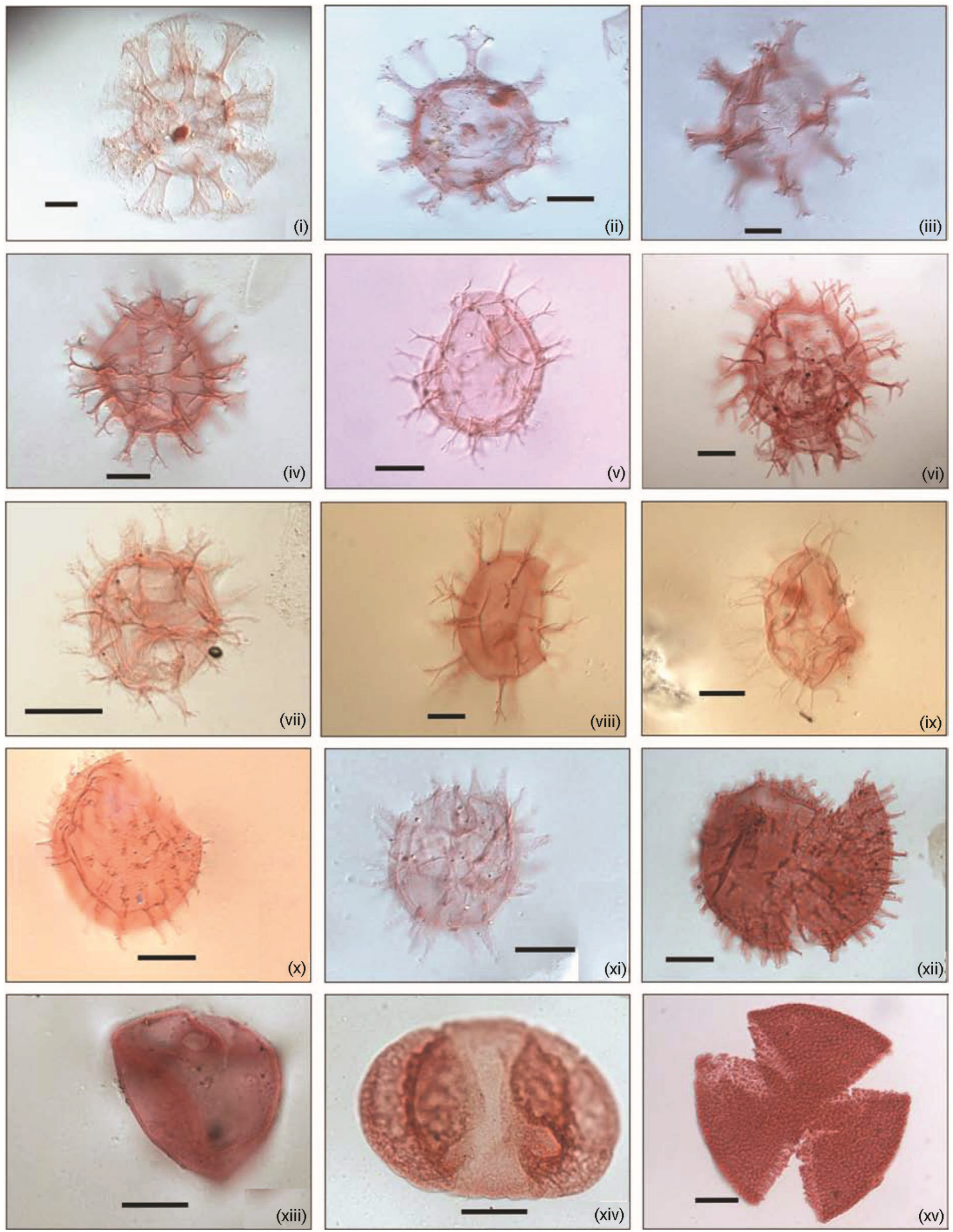

Figure 3. (i) Cordosphaeridium cantharellus (Brosius, 1963) Gocht, 1969, BSIP slide no. 16282, G37/29. (ii) Hystrichosphaeridium sp., BSIP slide no. 16282, N49/3. (iii) Homotryblium plectilum Drugg and Loeblich, 1967, BSIP slide no. 16277, G52. (iv) Spiniferites sp., BSIP slide no. 16276, O32/1. (v) Achomosphaera sp.1, BSIP slide no. 16282, T31. (vi) Spiniferites mirabilis (Rossignol, 1964) Matsuoka, 1974, BSIP slide no. 16277, M62/2. (vii) Spiniferites ramosus (Ehrenberg, 1838) Mantell, 1854 emend. Williams, 2001, BSIP slide no. 16282, J35/4. (viii) Achomosphaera sp. 2, BSIP slide no. 16282, O34/1. (ix) Distatodinium sp., BSIP slide no. 16282, O48. (x) Operculodinium centrocarpum (Deflandre and Cookson, 1955) Wall, 1967, BSIP slide no. 16282, H55. (xi) Dapsilidinium pseudocolligerum (Stover, 1977) Bujak et al., 1980, BSIP Slide No. 16282, N40. (xii) Polysphaeridium zohrayi (Rossignol, 1962) Bujak et al., 1980, BSIP slide no. 16276, T43. (xiii) Graminidites sp., BSIP slide no. 16282, G58. (xiv) Abiespollenites sp., BSIP slide no. 16276, U47/3. (xv) Dipterocarpuspollenites retipilatus Kar, 1992, BSIP slide no. 16277, M65. Scale bar $=10 \mu \mathrm{m}$ for each photomicrograph. 

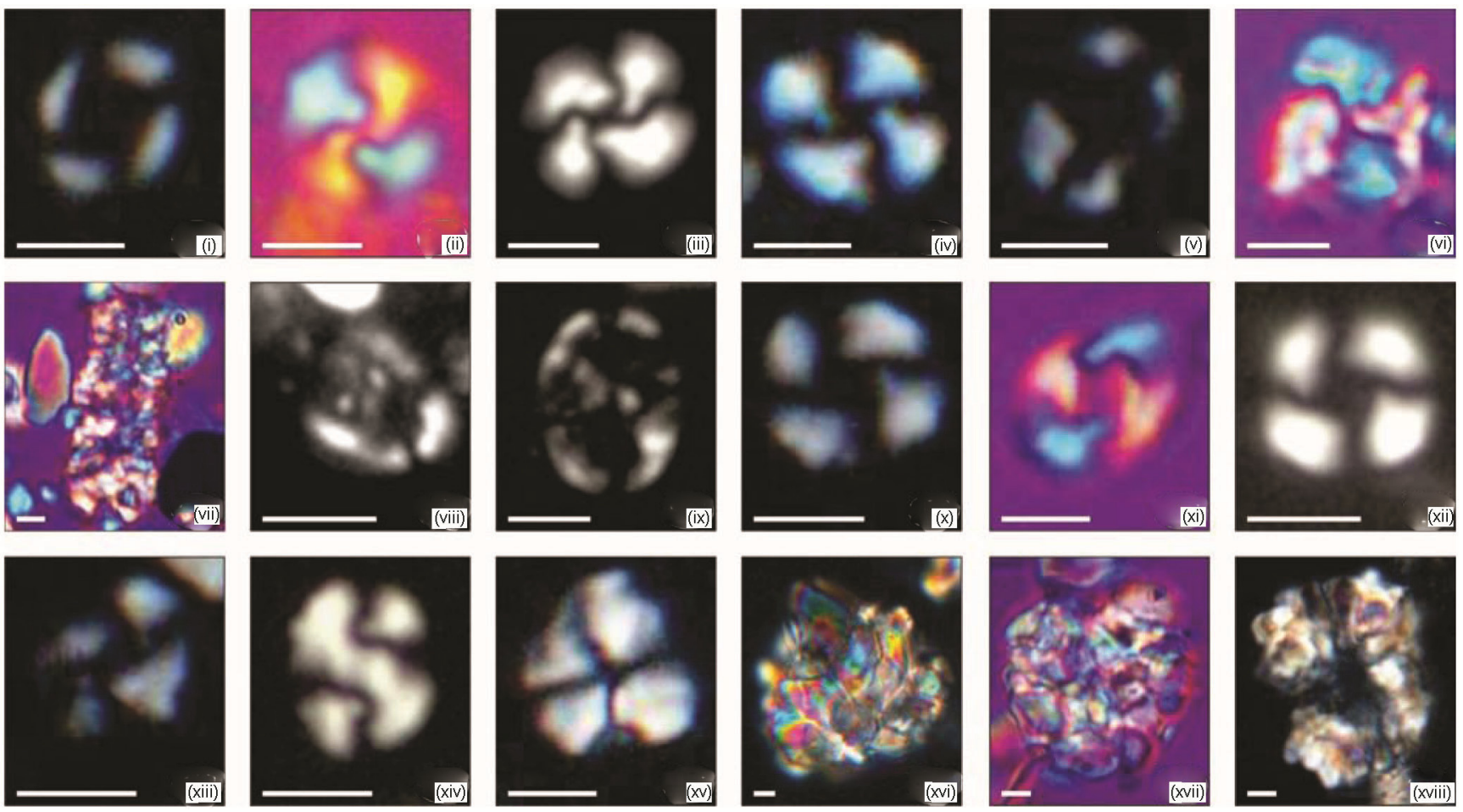

Figure 4. (i) Coronocyclus sp.; (ii)-(iv) Cyclicargolithus floridanus (Roth and Hay in Hay et al., 1967) Bukry, 1971; (v) Eiffellithus sp.; (vi) Micula murus (Martini, 1961) Bukry, 1973; (vii) Nannoconus sp.; (viii), (ix) Neochiastozygus sp.; (x)-(xii) Reticulofenestra circus de Kaenel and Villa, 1996; (xiii) Reticulofenestra minuta Roth, 1970; (xiv) Reticulofenestra perplexa (Burns, 1975) Wise, 1983; (xv) Sphenolithus moriformis (Bronnimann and Stradner, 1960) Bramlette and Wilcoxon, 1967; (xvi)-(xviii) Ascidian spicules. Scale bar $=2 \mu \mathrm{m}$ for each photomicrograph.

respective slides housed in the BSIP museum repository (16283-16286).

Well-preserved age-diagnostic species of dinoflagellate cysts and nannofossils were recovered from all the samples (Table 2). Moderately to poorly preserved calcareous nannofossils were recorded from all four samples. The assemblage is mainly dominated by the ascidian spicules and Cyclicargolithus floridanus. The productivity is fair in the bottom three samples (MFF 1-3) and reasonably good in the top sample (MFF 4). The diversity is also fair in all the four samples; only 10 nannotaxa are recorded, including reworked taxa of Cretaceous age. The nannofossil assemblage is composed of Coronocyclus sp., Cyclicargolithus floridanus, Eiffellithus sp., Micula murus, Nannoconus sp., Neochiastozygus sp., Reticulofenestra circus, Reticulofenestra minuta, Reticulofenestra perplexa and Sphenolithus moriformis.

$R$. circus was first recorded by de Kaenel and Villa ${ }^{20}$ from ODP Site 900, Iberia Abyssal Plain, northeastern Atlantic Ocean. Its presence was restricted within early Oligocene nannofossil zones NP22 to NP23. The first occurrence (FO; $32.92 \mathrm{Ma}$ ) of $R$. circus occurred within the NP22 zone and the last occurrence (LO; $29.62 \mathrm{Ma}$ ) within the NP23 zone ${ }^{21}$. Therefore, the total presence of $R$. circus envisages the Early-Middle Rupelian (NP22NP23) age of the studied sequence (Figure 5).

In general, the palynological assemblage in all samples is dominated by marine phytoplankton over terrestrially derived organic matter and sporomorphs. The sporomorphs assemblage mainly consists of bisaccate (Abiespollenites sp.), Poaceae (Graminidites sp.) and Dipterocarpaceae (Dipterocarpuspollenites retipilatus) pollen. The diverse dinoflagellate cyst assemblage consists of 40 taxa, excluding a few unidentified ones. It is characterized by a large number of Operculodinium spp., Polysphaeridium spp., Homotryblium spp., SpiniferitesAchomosphaera complex and Cleistosphaeridium spp. The typical oceanic taxa such as Pentadinium and Impagidinium are also recorded in all samples. Most of the recovered taxa are long-ranging, which limits their use in age assignment. The stratigraphically most significant dinocysts are Achilleodinium biformoides, Achomosphaera alcicornu, Cleistosphaeridium diversispinosum, Impletophaeridium machaeroides, Polysphaeridium congregatum and Tuberculodinium vancampoae. The dinoflagellate studies from low latitudes of the northern hemisphere, suggest that FO of $A$. biformoides and A. alcicornu in the equatorial region is just above the Eocene-Oligocene boundary at $\sim 33.5$ and $\sim 33.9$ Ma respectively ${ }^{22,23}$. The Lumpy Clay Member section is characterized by presence of $C$. diversispinosum in all samples. Eaton et al. ${ }^{24}$ have reported the $C$. diversispinosum range from Ypresian to Rupelian in samples from the Grand Banks, offshore eastern Canada. More precisely, it is reported up to D14 na dinocyst subzone $(\sim 31 \mathrm{Ma})$ of Germany ${ }^{25,26}$. In the present study, LO of $C$. diversispinosum envisages an age 
Table 2. List of recovered calcareous nannofossil and organic-walled palynomorh taxa

\section{Calcareous nannofossils}

Ascidian spicules

Coronocyclus sp.

Cyclicargolithus floridanus (Roth and Hay, in Hay et al., 1967) Bukry, 1971

Eiffellithus sp.

Micula murus (Martini, 1961) Bukry, 1973

Namnocomus sp.

Neochiastozygus sp.

Reticulofenestra circus de Kaenel and Villa, 1996

Reticulofenestra minuta Roth, 1970

Reticulofenestra perplexa (Burns 1975) Wise1983

Sphenolithus moriformis (Bronnimann and Stradner, 1960) Bramlette and Wilcoxon, 1967

\section{Dinoflagellate cysts}

Achilleodinium biformoides (Eisenack, 1954) Eaton, 1976

Achomosphaera alcicormu (Eisenack, 1954) Davey and Williams, 1966

Achomosphaera spp.

Cleistosphaeridium diversispinosum (Davey et al., 1966) Eaton et al., 2001

Cleistosphaeridium placacanthum (Deflandre and Cookson, 1955) Eaton et al., 2001

Cordosphaeridium cantharellus (Brosius, 1963) Gocht, 1969

Cordosphaeridium spp.

Cribroperidinium $\mathrm{sp}$.

Cyclopsiella granosa (Matsuoka, 1983) Head et al., 1992

Cyclopsiella sp.

Dapsilidinium pseudocolligerum (Stover, 1977) Bujak et al., 1980

Distatodinium $\mathrm{sp}$.

Ecladopysis sp.

Homotryblium plectilum Drugg and Loeblich, 1967

Homotryblium tenuispinosum Davey and Williams, 1966

Homotryblium vallum Stover, 1977

Hystrichokolpoma rigaudiae Deflandre and Cookson, 1955

Hystrichokolpoma globulus Michoux, 1985

Hystrichosphaeridium sp.

Impletosphaeridium machaeroides Benedek, 1972

Impagidinium elegans (Cookson and Eisenack, 1965) Stover and Evitt, 1978

Impagidinium $\mathrm{sp}$.

Lingulodinium machaerophorum (Deflandre and Cookson, 1955) Wall, 1967

Lanternosphaeridium sp.

Operculodinium centrocarpum (Deflandre and Cookson, 1955) Wall, 1967

Operculodinium microtriainum (Klumpp, 1953) Islam, 1983

Pentadinium laticinctum Gerlach, 1961

Pentadinium sp.

Polysphaeridium congregatum (Stover, 1977) Bujak et al., 1980

Polysphaeridium subtile Davey and Williams, 1966

Polysphaeridium zoharyi (Rossignol, 1962) Bujak et al., 1980

Spiniferites pseudofurcatus (Klumpp, 1953) Sarjeant, 1970 emend. Sarjeant, 1981

Spiniferites ramosus (Ehrenberg, 1838) Mantell, 1854 emend. Williams, 2001

Spiniferites mirabilis (Rossignol, 1964) Matsuoka, 1974

Spiniferites spp.

Tuberculodinium vancampoae (Rossignol, 1962) Wall, 1967

Undientified Gen et sp. 1

Undientified Gen et sp.2

Undientified Gen et sp.4

Spore-Pollen

Abiespollenites sp.

Graminidites sp.

Dipterocarpuspollenites retipilatus Kar, 1992

not younger than mid-Rupelian ( $\sim 31 \mathrm{Ma})$ for Lumpy Clay Member (Figure 5).

Originally $T$. vancampoae was reported from the Miocene $^{27}$, and studies from northwest Germany ${ }^{26}$ also placed its First Appearance Datum (FAD) in D16 dino- cysts zone (Early Miocene). However, its range was extended to late Oligocene $\sim 27 \mathrm{Ma}$ in offshore eastern Canada records long $\operatorname{ago}^{27-29}$. Interestingly, $T$. vancampoae was also encountered in the stratotype section of Rupelian in Belgium ${ }^{30}$ and NSO-3 biozone (Rupelian) of the 


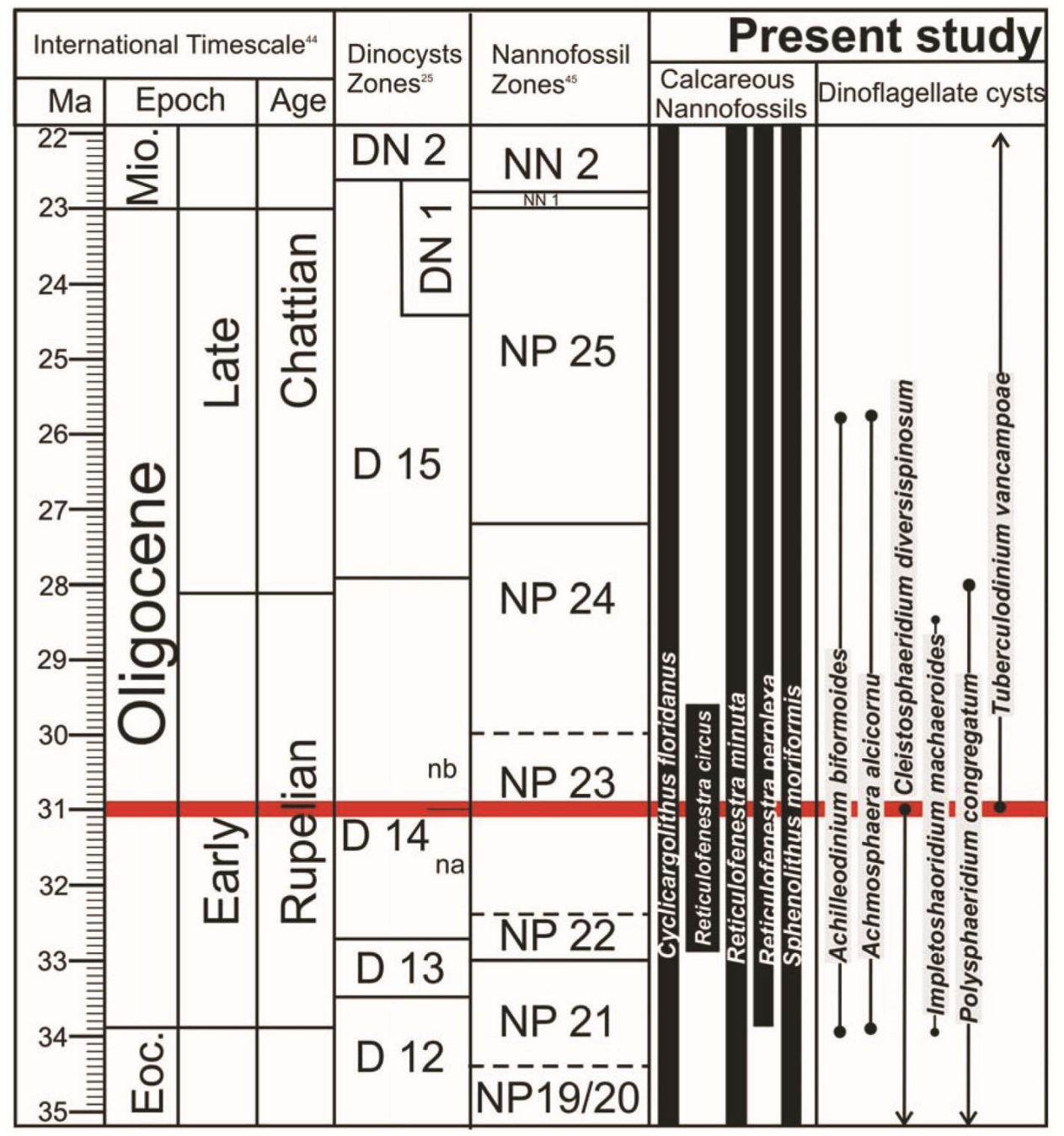

Figure 5. Composite representation of calcareous nannofossil and dinoflagellate cyst ranges and their correlation with standard calcareous nannofossil and dinoflagellate cyst zones.

North Sea Basin ${ }^{31}$. The recent records of T. vancampoae from eastern Equatorial Atlantic, West Africa ${ }^{32}$ mark its FO in Rupelian and have recalibrated its occurrence in $\mathrm{D} 14 \mathrm{nb}$ dinocysts subzone ${ }^{26}$. The other recovered dinocyst, I. machaeroides was recorded from Rupelian of Boom Clay Formation in Belgium ${ }^{33}$. The P. congregatum with its $\mathrm{LO}$ at $\sim 28 \mathrm{Ma}$ has also been commonly recorded in all samples ${ }^{29}$. The abundance of Spiniferites spp. and Homotryblium spp. in this succession is also known from Rupelian successions of the North Sea Basin ${ }^{31}$.

The Polysphaeridium group (Polysphaeridium spp. and Homotryblium spp.) generally occurs in the coastal, tropical-subtropical regions, where sea-surface salinity and temperature are high ${ }^{34}$. However, a few offshore occurrences, such as in the Atlantic shelf $f^{35}$ and ODP Hole $959 \mathrm{D}^{36}$ are also known. In the present study, abundant Polysphaeridium, Operculodinium and Homotryblium species are considered as indicative of inner neritic, possibly lagoonal environments with increased salinity ${ }^{37}$.
However, the Oligocene-Miocene dinocyst records of Denmark suggest that the genus Homotryblium produces cysts with different morphology of processes as a response to variations in salinity, and occurs in high abundance in low-salinity settings ${ }^{38}$. Lingulodinium machaerophorum is indicative of areas of increased nutrient availability ${ }^{39}$. Operculodinium, group which includes the genus Impletosphaeridium represents restricted marine to open marine neritic environments. The data suggest that most species of the SpiniferitesAchmosphaera complex can attain high abundances in near-shore and open marine settings ${ }^{40}$. The presence of typical oceanic taxa such as Impagidinium and Pentadinium indicates occasional incursion of open oceanic waters into neritic environment ${ }^{41-43}$. This may have possibly benefitted the calcareous nanoplankton to flourish in temporarily more offshore conditions.

The present preliminary study is an endeavour to precisely date the Lumpy Clay Member on the basis of 
integrated records of dinoflagellate cysts and calcareous nannofossils. The palynological results helped us to date the succession to Middle Rupelian ${ }^{44}(\sim 31 \mathrm{Ma})$. The inferred date corresponds to part of NP23 nannofossil zone $^{45}$ and the boundary between D14 na and D14 nb dinocysts subzones ${ }^{26}$. The palynological assemblage implies that the deposition took place mainly in shallow marine neritic lagoonal environment.

1. Miller, K. G. et al., The phanerozoic record of global sea-level change. Science, 2005, 310, 1293-1298.

2. Coxall, H. K. and Pearson, P. N., The Eocene-Oligocene transition. In Deep-Time Perspectives on Climate Change: Marrying the Signal from Computer Models and Biological Proxies (eds Williams, M. et al.), The Micropalaeontological Society, Special Publications, The Geological Society, London, 2007, vol. 2, pp. 351-387.

3. Adams, C. G., Butterlin, J. and Samanta, B. K., Larger foraminifera and events at the Eocene/Oligocene boundary in the Indo-West Pacific region. In Terminal Eocene Events (eds Pomerol, C. and Premoli Silva, I.), Elsevier, Amsterdam, 1986, pp. 237-252.

4. Renema, W., Larger foraminfera as marine environmental indicators. Scr. Geol., 2002, 124, 1-239.

5. Renema, W., Fauna development of larger benthic foraminifera in the Cenozoic of Southeast Asia. In Biogeography, Time, and Place: Distributions, Barriers, and Islands (ed. Renema, W.), Springer, Dordrecht, The Netherlands, 2007, pp. 179-215.

6. Wilson, M. E., Cenozoic carbonates in Southeast Asia: implications for equatorial carbonate development. Sediment. Geol., 2002, 147, 295-428.

7. Mukhopadhyay, S. K., Earliest Pellatispira Boussac from the middle Eocene of India: morphological speciality of the ancestral stock. J. Asian Earth Sci., 2003, 22, 209-225.

8. Sarangi, S., Sarkar, A., Bhattacharya, S. K. and Ray, A. K., Isotopic evidence of a rapid cooling and continuous sedimentation across the Eocene-Oligocene boundary of Wagapadhar and Waior, Kutch. J. Geol. Soc. India, 1998, 51, 245-248.

9. Sarangi, S., Sarkar, A., Bhattacharya, S. K., Ebihara, M. and Ray, A. K., Growth rate and life span of Eocene-Oligocene Nummulites tests: Inferences from $\mathrm{Sr} / \mathrm{Ca}$ ratio. Terra Nova, 2001, 13, 264-269.

10. Sarkar, A., Sarangi, S., Ebihara, M., Bhattacharya, S. K. and Ray, A. K., Carbonate geochemistry across the Eocene/Oligocene boundary of Kutch, western India: implications to oceanic $\mathrm{O}_{2}$-poor condition and foraminiferal extinction. Chem. Geol., 2003, 201, 281-293.

11. Nagappa, Y., Foraminiferal biostratigraphy of the CretaceousEocene succession in the India-Pakistan-Burma region. Micropalaeontology, 1959, 5(2), 145-192.

12. Chatterji, A. K. and Mathur, U. B., A note on the Nari Series of Kutch, Gujarat. Bull. Geol. Soc. India, 1966, 3(1), 9-11.

13. Biswas, S. K. and Raju, D. S. N., Note on the rock-stratigraphic classification of Tertiary sediments of Kutch. Q. J. Geol. Min. Met. Soc. India, 1971, 43(3), 177-180.

14. Biswas, S. K., Tertiary stratigraphy of Kutch. J. Palaeontol. Soc. India, 1992, 37, 1-29.

15. Biswas, S. K., A note on the geology of Kutch, Gujarat Q. J. Geol. Min. Metall. Soc. India, 1971, 43, 223-235.

16. Biswas, S. K., Time stratigraphic classification of the Tertiary rocks of Kutch $-\mathrm{a}$ revision and amendments. Q. J. Geol. Min. Metall. Soc. India, 1973, 44(3), 223-235.

17. Biswas, S. K., A new classification of the Tertiary rocks of Kutch, western India. Bull. Geol. Min. Metall. Soc. India, 1965, 35, 1-6.
18. Kumar, A. and Saraswati, P. K., Response of larger foraminifera to mixed carbonate - siliciclastic environments: an example from the Oligocene-Miocene sequence of Kutch, India. Palaeogeogr., Palaeoclimatol., Palaeoecol., 1997, 136, 53-65.

19. Bown, P. R. and Young, J. R., Techniques. In Calcareous Nannofossil Biostratigraphy (ed. Bown, P. R.), Cambridge University Press, Chapman and Hall, London, 1998, pp. 16-28.

20. de Kaenel, E. and Villa, G., Oligocene-Miocene calcareous nannofossil biostratigraphy and paleoecology from the Iberia Abyssal Plain. In Proceedings of the ODP, Scientific Results (eds Whitmarsh, R. B. et al.), 1996, vol. 149, pp. 79-145; doi:10.2973/odp. proc.sr.149.208.1996

21. http://www.mikrotax.org/Nannotax3/index.php?dir=Coccolithophores/ Isochrysidales/Noelaerhabdaceae/Reticulofenestra/R.\%20umbilicus \%20group/Reticulofenestra\%20circus

22. Brinkhuis, H. and Biffi, U., Dinoflagellate cyst stratigraphy of the Eocene/Oligocene transition in central Italy. Mar. Micropaleontol., 1993, 22, 131-183.

23. Williams, G. L., Brinkhuis, H., Pearce, M. A., Fensome, R. A. and Weegink, J. W., Southern Ocean and Global dinoflagellate cyst events compared: index events for the Late Cretaceous-Neogene. In Proceedings of the Ocean Drilling Program, Scientific Results (eds. Exon, N. F., Kennett, J. P. and Malone, M. J.), 2004, vol. 189, pp. 1-98.

24. Eaton, G. L., Fensome, R. A., Riding, J. B. and Williams, G. L., Re-evaluation of the status of the dinoflagellate cyst genus Cleistosphaeridium. N. Jb. Geol. Abh., 2001, 219, 171-205.

25. Köthe, A., Paleogene dinoflagellates from Northwest Germany biostratigraphy and paleoenvironment. Geol. Jahrb. A, 1990, 118, 3-111.

26. Köthe, A. and Piesker, B., Stratigraphic distribution of Paleogene and Miocene dinocysts in Germany. Rev. Paléobiol., 2007, 26(1), $1-39$.

27. Benedek, P. N., Ergebnisse der Phytoplankton-Untersuchungen aus dem Nordwestdeutschen Tertiär. In Nordwestdeutschland im Tertiär-Beiträge Regzur Regionalen (ed. Tobien, H.), Beiträge zur regionalen Geologie der Erde, 1986, vol. 18, pp. 157185.

28. Williams, G. L. and Bujak, J. P., Distribution patterns of some North Atlantic Cenozoic dinoflagellate cysts. Mar. Micropaleontol., 1977, 2, 223-233.

29. Williams, G. L., Stover, L. and Kidson, E. J., Morphology and stratigraphic ranges of selected Mesozoic-Cenozoic dinoflagellate taxa in the Northern Hemisphere. Geol. Surv. Can. Pap., 1993, 92(10), 1-137.

30. De Coninck, J., Organic-walled phytoplankton biostratigraphy of the Eocene-Oligocene transition in the Kallo borehole and the Rupelian stratotype area (North-western Belgium). Bull. Soc. Belge Géol., 1999, 105, 171-209.

31. Van Simaeys, S., Munsterman, D. and Brinkhuis, H., Oligocene dinoflagellate cyst biostratigraphy of the southern North Sea Basin. Rev. Palaeobot. Palynol., 2005, 134, 105-128.

32. Awad, W. K. and Oboh-Ikuenobe, F. E., Late Paleogene-early Neogene dinoflagellate cyst biostratigraphy of the eastern Equatorial Atlantic. J. Afr. Earth Sci., 2018, 140, 267-231.

33. Stover, L. E. and Hardenbol, J., Dinoflagellates and depositional sequences in the Lower Oligocene (Rupelian) Boom Clay Formation, Belgium. Bull. Soc. Belge Geol., 1994, 102(1-2), 5-77.

34. Zonneveld, K. A. F. et al., Atlas of modern dinoflagellate cyst distribution based on 2405 data points. Rev. Palaeobot. Palynol., 2013, 191, 1-197.

35. Stover, L. E., Oligocene and Early Miocene dinoflagellates from Atlantic Corehole 5/5B, Blake Plateau. Am. Assoc. Strat. Palynol., Contrib. Ser. A, 1977, 5, 66-89.

36. Awad, W. K. and Oboh-Ikuenobe, F. E., Early Paleogene dinoflagellate cysts from ODP Hole 959D in the Côte d'Ivoire-Ghana Transform Margin, West Africa: new species, biostratigraphy and 
paleoenvironmental implications. J. Afr. Earth Sci., 2016, 123, 123-144.

37. Brinkhuis, H., Late Eocene to Early Oligocene dinoflagellate cysts from the Priabonian type-area (northeast Italy): biostratigraphy and paleoenvironmental interpretation. Palaeogeogr., Palaeoclimatol., Palaeoecol., 1994, 107, 121-163.

38. Dybkjaer, K., Morphological and abundance variations in Homotryblium-cyst assemblages related to depositional environments; uppermost Oligocene-Lower Miocene, Jylland, Denmark. Palaeogeogr., Palaeoclimatol., Palaeoecol., 2004, 206, 41-58.

39. Dale, B. and Fjellsa, A., Dinoflagellate cysts as paleoproductivity indicators: state of the art, potential, and limits. In Carbon Cycling in the Glacial Ocean: Constraints on the Ocean's Role in Global Change (eds Zahn, R. et al.), Springer-Verlag, Berlin, 1994, pp. 521-537.

40. Edwards, L. E., New semiquantitative (paleo) temperature estimates using dinoflagellate cysts, an example from the North Atlantic Ocean. In Neogene and Quaternary Dinoflagellate Cysts and Acritarchs (eds Head, M. J. and Wrenn, J. H.), American Association of Stratigraphic Palynologists Foundation, Dallas, Texas, USA, 1992, pp. 69-87.

41. Wall, D., Dale, B., Lohmann, G. P. and Smith, W. K., The environmental and climatic distribution of dinoflagellate cysts in modern marine sediments from regions in the North and South Atlantic Oceans and adjacent areas. Mar. Micropaleontol., 1977, 2, 121200.

42. Edwards, L. E. and Andrle, V. A. S., Distribution of selected dinoflagellate cysts in modern marine sediments. In Neogene and Quaternary Dinoflagellate Cysts and Acritarchs (eds Head, M. J. and Wrenn, J. H.), American Association of Stratigraphic Palynologists Foundation, Texas, USA, 1992, pp. 259-288.

43. Udeze, C. U. and Oboh-Ikuenobe, F. E., Neogene paleoceanographic and paleoclimatic events inferred from palynological data: Cape Basin off South Africa, ODP Leg 175. Palaeogeogr., Palaeoclimatol., Palaeoecol., 2005, 219, 199-223.

44. Ogg, J. G., Ogg, G. and Gradstein, F. M., A Concise Geologic Time Scale, Elsevier, 2016, pp. 1-240; ISBN: 9780444637710.

45. Martini, E., Standard Tertiary and Quaternary calcareous nannoplankton zonation. In Proceedings of the Second Planktonic Conference Roma 1970 (ed. Farinacci, A.), Edizioni Tecnoscienza, Rome, 1971, vol. 2, pp. 739-785.

ACKNOWLEDGEMENTS. We thank the Director, Birbal Sahni Institute of Palaeosciences, Lucknow for providing necessary facilities and permission (BSIP/RDCC/Publication no. 95/2017-18) for this publication. P.V. also thank Dr M. R. Rao for his help and constant encouragement.

Received 12 April 2018; revised accepted 6 March 2019

doi: $10.18520 / \mathrm{cs} / \mathrm{v} 116 / \mathrm{i} 9 / 1571-1580$

\section{Water retention and transmission characteristics of containerized growing media amended with differential proportions of compressed coir bricks}

\author{
Simrat Singh ${ }^{1, *}$, S. S. Kukal ${ }^{2}$ and R. K. Dubey ${ }^{1}$ \\ ${ }^{1}$ Department of Floriculture and Landscaping, and \\ ${ }^{2}$ Department of Soil Science, Punjab Agricultural University, \\ Ludhiana 141 004, India
}

The hydraulic characteristics of growing media play an equally important role as do the architectural properties in the production of ornamental potted plants. The reuse of biological agri-wastes, amended with cocopeat and soil, has potential for ameliorating the hydro-physical environment in growing media substrates, affecting air-water relations. A study was undertaken to evaluate the water retention and transmission characteristics of four biological wastes as base media (farmyard manure (FYM), leaf mould (LM), rice husk ash (RHA) and composted sewage sludge (CSS)) amended with different proportions of soil : coir mixture $(0: 75,25: 50,50: 25,75: 0)$ respectively. These media mixtures were filled in 3.51 pots. Utilization of coir $<50 \%$ (per cent of pot volume) as an amendment in FYM and CSS-based media mixtures improved hydraulic characteristics of pot-growing media. The use of RHA amended with soil : coir was not suitable as a growing medium due to higher relative evaporation rate and higher rate of infiltration. Water retention in terms of maximum water-holding capacity and available water increased with coir addition, the increase being enormous with $75 \%$ coir. Infiltration rate of water in the media improved with addition of coir (0-50\%), showing a steep increase $\left(4.25-8.10 \mathrm{~cm} \mathrm{~min}^{-1}\right)$ at highest $(75 \%)$ proportion of coir. Drainage rate was highest in FYM and LMbased media mixtures.

Keywords: Coir bricks, hydraulic characteristics, infiltration rate, pot media, water retention.

CONTAINERIZED ornamental plants are not only confined to private homes, but also aesthetically placed in mass multiplexes due to scarcity of spaces for beautification. Production of sustainable ${ }^{1}$, environment-friendly substrates $^{2}$, also referred to as growing media, has been utilized as an amendment for improving physio-chemical characteristics of media contained in finite-volume pots. However, research on pot-media hydraulics is still in its infancy, which is of vital importance to ornamental potted plant industry worldwide. The hydraulic characteristics responsible for air-water relations have been

*For correspondence. (e-mail: simratflori@pau.edu) 